\title{
Antibacterial and Cytotoxic Potential of Biosynthesized Silver Nanoparticles by Some Plant Extracts
}

\author{
Afrah E. Mohammed * (D), Alaa Al-Qahtani, Amal al-Mutairi, Bashayir Al-Shamri \\ and Kawther Aabed ${ }^{+}$(iD \\ Department of Biology, Faculty of Sciences, Princess Nourah Bint Abdulrahman University, \\ 11474 Riyadh, Saudi Arabia; aaxx0013@hotmail.com (A.A.-Q.); Amlhadi-@hotmail.com (A.a.-M.); \\ besh053@hotmail.com (B.A.-S.); dr.kaabed@gmail.com (K.F.A.) \\ * Correspondence: farhati@hotmail.com; Tel.: +966-566-675-853 \\ + This author is the principal investigator of this work.
}

Received: 7 May 2018; Accepted: 26 May 2018; Published: 30 May 2018

check for updates

\begin{abstract}
The provision of nanoparticles using biogenic material as a part of green chemistry is an attractive nanotechnology. The current research aimed to test the antimicrobial and cytotoxic efficacy of silver nanoparticles synthesized by extracts of Phoenix dactylifera, Ferula asafetida, and Acacia nilotica as reductant and stabilizing agents in silver nanoparticle formation. Synthesized nanoparticles were evaluated for their antimicrobial activity against Staphylococcus aureus (Gram-positive) and Pseudomonas aeruginosa and Escherichia coli (Gram-negative) using an agar well diffusion assay. Furthermore, cytotoxic ability was investigated against LoVo cells. The potential phyto-constituents of plant extracts were identified by Fourier-transform infrared spectroscopy (FT-IR) techniques. Field emission scanning electron microscopy (FE-SEM), transmission electron microscope (TEM), and zeta potential analyzed the size and morphology of the biogenic nanoparticles. The current study revealed the ability of the tested plant extract to convert silver ions to silver nanoparticles with an average size that ranged between $67.8 \pm 0.3$ and $155.7 \pm 1.5 \mathrm{~nm}$ in diameter. Biogenic AgNPs showed significant antibacterial ability (10 to $32 \mathrm{~mm}$ diameter) and anticancer ability against a LoVo cell with IC50 ranged between $35.15-56.73 \mu \mathrm{g} / \mathrm{mL}$. The innovation of the present study is that the green synthesis of NPs, which is simple and cost effective, provides stable nano-materials and can be an alternative for the large-scale synthesis of silver nanoparticles.
\end{abstract}

Keywords: AgNPs; Phoenix dactylifera; Acacia nilotica; Ferula asafoetida; antibacterial; cytotoxicity

\section{Introduction}

Recently, worldwide problems associated with environmental concerns have led to a focus on the technology of green chemistry as an environmentally friendly process in chemistry to overcome different health problems [1]. The development of antibiotic resistant bacteria is highly associated with an increase in antibiotic usage and is one of the recent global health problems. Consequently, great efforts are being made to look for alternatives to antibiotics to stop the development of antibiotic resistant microbes. Silver is one of the metal ions that has shown potential bactericidal, anti-fungal, and anti-inflammatory effects [2,3]. Furthermore, silver in the form of nanoparticles (AgNPs) has been used against microorganisms and exhibited a promising way to resolve the development of antibiotic-resistant bacteria [4]. AgNPs and their role as cytotoxic materials against cancer cells was reported in $[5,6]$. The conversion of silver ion to silver nanoparticles using chemical reduction, ion sputtering, and sol gel are well known techniques [7-10], but such practices may have a negative environmental influence since hazardous chemicals might be included in such a conversion; therefore, looking for environmentally friendly alternatives is necessary. A green 
synthesis of nanoparticles using biological material showed an advantage over other methods since it is simple, cost effective, and produces a stable product [11]. Plant extracts and microorganisms can be utilized to convert metal ion to metal nanoparticles as an alternative to conventional methods. Recent studies used different plant extracts as a mediator for silver nanoparticle formation such as Eucalyptus camaldulensis, Ziziphus spina christi, Calligonum comosum, marigold flower and Ziziphora tenuior, Azadirachta indica [7,9,12-16], and Erythrina indica [10]. On the other hand, different microbes were also studied as the bio-mediator in silver nanoparticle formation such as E. coli [17], a cell-free supernatant derived from Bacillus sp. culture [18], Aspergillus flavus, Lactic acid bacteria, Bacillus licheniformis, and Bacillus cereus, [19-22], but plant extracts showed a higher ability for the conversion of Ag ions to AgNPs compared to conversion mediated by microorganisms [23]. This might be due to the fact that plants are a rich source of biologically active compounds such as flavones, ketones, aldehydes, amides, carboxylic acids, proteins, DNA, and enzymes. Such compounds act as bio-reducing agents and mediate the reduction process of Ag ions to AgNPs [24]. On the other hand, the antimicrobial ability of AgNPs against a wide spectrum of MDR pathogens was largely investigated [25-27]. A recent study suggested the mechanism of AgNPs on bacterial cell death is its influence on membrane morphology that leads to improper permeability and material transport [28]. Plant extracts and their high potentiality in AgNPs biosynthesis, beside their antibacterial and cytotoxicity, were the aims of the current investigation since the plant is a rich source of phytochemicals. In this context, the extract of date palm Phoenix dactylifera L. is studied. Date palm is one of the fruit trees in the Arab region that it is widely grown and has edible sweet fruit. Recently, different studies investigated the ability of the Phoenix dactylifera fruit and plant leaves aqueous extract in the synthesis of AgNPs and palladium nanoparticles [29-31]. Ajwa, a type of date that is only cultivated in Al-Madinah Al-Munawara/Saudi Arabia, is investigated. Ajwa showed a high free radical scavenging ability via its antioxidant properties and a high content of poly phenol with a highly significant impact on disease cures in different studies [32,33]. On the other hand, Acacia nilotica, is a medicinal plant that has a high antioxidant capability [34]. A. nilotica gum extract was recently used as the biomediator in AgNPs formation [35]. Furthermore, a plant of the Ferula asafoetida L. variety is common in Iran and a main source of asafetida, which is produced by the plant as the root exudates [36]. As a result, it is one of the target plants in the current study. Synthesized AgNPs using Phoenix dactylifer, Acacia nilotica, and Ferula asafoetida were detected by a scanning electron microscope (SEM), transmission electron microscope (TEM), and zeta potential. Furthermore, the bactericidal activity of AgNPs was tested against three human pathogenic bacteria for minimum inhibitory concentration (MIC) determination. The cytotoxic effect was also determined against LoVo cell lines by 3-(4,5-dimethyl-2-thiazolyl)-2,5-diphenyl-tetrazolium bromide (MTT) assay.

\section{Materials and Methods}

\subsection{Collection and Storage of Plant Samples}

The fruit samples of Acacia nilotica and Ferula asafoetida were collected from the Riyadh region in Saudi Arabia, and Phoenix dactylifera L. (Ajwah) was collected from the Almadinah Almunawwarah region in Saudi Arabia. Samples were labelled and stored at $4{ }^{\circ} \mathrm{C}$ in polythene bags for further processing. The plant parts were washed with distilled water and dried. Dried samples were ground well into a fine powder with the help of a milling machine (IKA werke, GMBH and Co., Staufen im Breisgau, Germany). The powder was stored in air sealed plastic containers at room temperature for extraction and further analysis.

\subsection{Synthesis of Silver Nanoparticles (AgNPs)}

Aqueous and ethanolic extracts were prepared from the collected plant materials by adding $10 \mathrm{~g}$ powder to $100 \mathrm{~mL}$ solvent. Heat treatment for $10 \mathrm{~min}$ at $80{ }^{\circ} \mathrm{C}$ to stop the enzymes activity was performed on the aqueous extract. The solution then filtered through whatman candidate No. 1 (pore size $125 \mathrm{~mm}$, 
Maidstone, England,). Furthermore, the ethanolic extract was kept overnight and then filtered through the same whatman candidate mentioned above. Filtrate was heated for the concentration of the extract and then kept for further use. For the synthesis of the AgNPs, $10 \mathrm{~mL}$ of each prepared extract as reducing and capping agents were mixed with $90 \mathrm{~mL}$ of a $1 \mathrm{mM} \mathrm{AgNO}_{3}$ solution in an Erlenmeyer flask and allowed to react at room temperature for $48 \mathrm{~h}$. For each sample, preparation was done three times for repeatability. AgNPs were stored for further study at temperature of $4{ }^{\circ} \mathrm{C}$.

\subsection{Characterization of Biogenic AgNPs}

UV Spectroscopy, Dynamic light scattering, zeta potential, field emission scanning electron microscopy (Peabody, MA, USA), and transmission electron microscopy (Peabody, MA, USA) were used for detection of biogenic AgNPs as follows:

\subsubsection{UV Spectroscopy}

UV-visible spectrophotometer (Shimadzu, Tokyo, Japan) was used for the characterization of AgNPs. The reduction of pure $\mathrm{Ag}^{+}$ions was checked by measuring at UV-2450 double-beam (200-800 nm).

\subsubsection{Dynamic Light Scattering (DLS) and Zeta Potential}

A Zetasizer nano device (Malvern, Worcestershire, UK) was used to measure the size and distribution of AgNPs prepared by plant extracts.

\subsubsection{Field Emission Scanning Electron Microscopy (FE-SEM)}

The FE-SEM technique (JEOL 7500FA JEOL, Peabody, MA, USA) was used to reveal information about the sample, including the external morphology materials making up the samples. A drop of nanoparticle suspensions with a volume of $8 \mu \mathrm{L}$ was placed onto 200 mesh grids with a carbon support film (Agar Scientific, London, UK) and dried. Furthermore, the sample was rinsed with EtOH, dried and fixed on an appropriate SEM holder. Images were taken at an accelerating voltage of $30 \mathrm{kV}$. JEOL JEM-2100 (JEOL, Peabody, MA, USA).

\subsubsection{Transmission Electron Microscopy (TEM)}

TEM a JEOL JEM-1011 (JEOL, Peabody, MA, USA) was used for size, shape, and crystallinity characterization of the biogenic AgNPs. Samples were prepared by placing a small drop with a volume of $8 \mu \mathrm{L}$ on a carbon coated copper grid of 300 meshes. Images were taken at an acceleration voltage of $200 \mathrm{kV}$.

\subsubsection{Fourier-Transform Infrared Spectroscopy (FT-IR)}

FT-IR is a method of measuring infrared absorption and emission spectra of the biomolecules found in the prepared samples. A range of $500-4000 \mathrm{~cm}^{-1}$ FT-IR (Nicolet 6700 FT-IR Spectrometer, Waltham, MA, USA) was used.

\subsection{Evaluation of the Antibacterial Activity of AgNPs}

The antibacterial activity of AgNPs was determined using well agar diffusion methods [14]. Three types of bacteria, Staphylococcus aureus from the Gram-positive group and Pseudomonas aeruginosa and Escherichia coli from the Gram-negative group, were tested. Pure cultures of the microorganisms were sub-cultured on Mueller-Hinton Agar. $0.2 \mathrm{~mL}$ of bacteria strain $\left(2.5 \times 10^{5} \mathrm{CFU} / \mathrm{mL}\right)$ was swabbed uniformly onto individual agar plates using sterile swabs. Subsequently, three adequately spaced wells (holes), each $4 \mathrm{~mm}$ in diameter, were made per plate at the culture agar surface using a sterile metal cork borer. In each hole, $0.2 \mathrm{~mL}$ of extract was used under aseptic conditions, kept at room temperature for one hour to allow the extracts to diffuse into agar medium and incubated accordingly. Sterile distilled water was used as the reference negative control. Plates were incubated at $37^{\circ} \mathrm{C}$ for 18-24 h. Inhibition zones that appeared as a clear area around the wells were evaluated. 
2.4.1. Minimum Inhibitory Concentration (MIC) and Minimum Bactericidal Concentration (MBC) Determination

The MIC and MBC values were determined by a micro dilution method in NB. $10 \mu \mathrm{L}$ of bacterial strain containing $2.5 \times 10^{5} \mathrm{CFU} / \mathrm{mL}$, bacteria was added individually to $10 \mathrm{~mL}$ of $\mathrm{NB}$. Different concentrations of AgNPs were added to the test tubes containing the bacterial strains and incubated for $24 \mathrm{~h}$. After incubation, the MIC values were obtained by checking the turbidity of the bacterial growth. The MIC value corresponded to the concentration that inhibited $99 \%$ of bacterial growth. Furthermore, the lowest concentration of AgNPs that completely killed the tested bacteria was considered as the MBC [28].

\subsubsection{Tolerance Level}

The tolerance levels against AgNPs were determined for each bacterial strain using the following formula [37].

\section{Tolerance $=\mathrm{MBC} / \mathrm{MIC}$}

The bactericidal capacity of the analyzed compound was detected by the tolerance level reflecting the bactericidal and bacteriostatic agents against tested microbes. If the ratio is $\geq 16$, then the agent has a bacteriostatic effect whereas the ratio $\leq 4$ reflects the bactericidal ability of the examined material [38].

On the other hand, to study the interaction of biogenic AgNPs with tested microbes, bacillus sp. was assessed using FE-SEM. Broth containing Pseudomonas aeruginosa exposed to AgNPs was subjected to SEM after $24 \mathrm{~h}$.

\subsubsection{Synergistic Antibacterial Potential Silver Nanoparticles}

The synergistic antibacterial effect of AgNPs and Amoxicillin, Ciprofloxacin and Cefuroxime as standard antibiotics was tested against S. aureus, P. aeruginosa, and E. coli using a disk diffusion method (Naqvi et al., 2013). Fresh cultured bacteria were used to study the synergistic effect. The antibiotic disks were mixed by $1 \mathrm{~mL}$ of AgNPs and placed at the plates cultured with bacteria. The synergistic antibacterial activity of AgNPs and antibiotics combination was measured after $24 \mathrm{~h}$ of incubation at $37^{\circ} \mathrm{C}$ as diameter of inhibition zone around the disks $(\mathrm{mm})$.

\subsection{Cancer Cell Lines and Culture Conditions}

LoVo cells lines were obtained from the Faculty of Science, Kind Saud University, Riyadh, Saudi Arabia. The cytotoxic potency of AgNPs mediated by plant extract was tested against LoVo cell lines by the MTT test, which depends on the reduction of MTT tetrazolium salt to purple formazan due to the presence of metabolically active cells [39]. A Beckman Coulter spectrophotometer (USA) was used for the MTT test to estimate the proliferation rates at $595 \mathrm{~nm}$. The viable cell percentage was calculated, taking into account the $100 \%$ viability of untreated cells. $50 \%$ of the Inhibitory Concentration (IC50) was used for the cytomorphological observation. After the treatment, the cells (control and treated) were washed with PBS and fixed at 1:1 ratio of methanol and glacial acetic acid for $1 \mathrm{~h}$ at room temperature.

$$
\text { Viability } \%=\frac{\text { OD sample }}{\text { OD control }} \times 100
$$

\section{Statistical Analysis}

Each test in the present investigation was performed at least three times for repetitions; means and standard deviations were calculated using Microsoft Excel 2013. The SEM and TEM images of the AgNPs were chosen from one of the repetitions. 


\section{Results and Discussion}

\subsection{AgNPs Synthesis Using Plant Extracts and AgNPs Characterization}

Results from the current investigation revealed that the addition of the aqueous or ethanolic plant extract of Phoenix dactylifera, Acacia nilotica, and Ferula asafoetida to the silver in the form of a nitrate $(0.1 \mathrm{mM})$ led to a color change of the mixture from yellowish to brown, indicating the excitation of plasmon resonance of AgNPs [3]. The color change of the mixture was time dependent, after $48 \mathrm{~h}$ the color was stable and appeared to be dark brown. For observing the bio-reduction process of Ag ions to AgNPs UV-vis spectroscopy was used. Absorption peaks of the mixture of AgNPs and plant extract showed silver surface plasmon resonance at 420, $425 \mathrm{~nm}, 430,440 \mathrm{~nm}$, and $430 \mathrm{~nm}$ for AgNPs prepared by aqueous and alcoholic extracts of Phoenix dactylifer, Acacia nilotica, and Ferula asafetida, respectively. SEM and TEM were used to study the AgNPs morphology, surface shape and size. Figures 1 and 2 present the SEM image and corresponding TEM images for the AgNPs prepared by different plant materials in the current study. Figure 1a-c shows AgNPs obtained by using alcoholic extracts of Phoenix dactylifer, Acacia nilotica, and Ferula asafoetida. Figure 2a-c shows AgNPs obtained using aqueous extracts of Phoenix dactylifer, Acacia nilotica, and Ferula asafetida. Spherical shaped AgNPs were obtained from the Phoenix dactylifer ethanolic and aqueous extract using SEM and TEM; the same observations were also recorded [30] with a size of 20-60 nm. In the current study the aqueous extract of the Phoenix dactylifer showed an average size of $67 \mathrm{~nm}$, but the ethanolic extract showed a relatively higher size $(121 \mathrm{~nm})$. Regarding AgNPs prepared by Ferula asafoetida, SEM and TEM indicated spherical shapes for both extraction methods with an average size of 105.7 and $155.7 \mathrm{~nm}$ for aqueous and ethanolic extracts respectively. A similar observation regarding the shape was also recorded by Sangeetha et al. [40], yet they found relatively small particle sizes (10.4 nm). Polydispersed and spherical shaped AgNPs prepared by Acacia nilotica with particle sizes of 100.4 and 147 nm were detected in the current study using SEM and TEM images. A range of 30-150 nm was recorded by Usha and Rachel in 2014 when they studied A. nilotica leaves. Furthermore, AgNPs prepared by aqueous and ethanolic extract of Phoenix dactylifer showed a mean zeta potential of -5.4 and $-14 \mathrm{mV}$, respectively, while $-35 \mathrm{mV}$ was recorded by Farhadi et al. [41], and AgNPs prepared by aqueous and ethanolic extract of F. asafoetida showed mean values of -0.2 and $-12 \mathrm{mV}$ respectively. -14 and $-15 \mathrm{mV}$ were observed by Sangeetha et al. [40]. -0.2 and $-13.2 \mathrm{mV}$ were detected in the current study for AgNPs prepared by aqueous and thanolic extract of Acacia nilotica, respectively. AgNPs prepared by ethanolic extract showed higher a negative value than the AgNPs prepared by aqueous extract for all different plants used, indicating higher stability for the AgNPs since high negative values demonstrate the repulsion between the particles and therefore achieve stable AgNPs without accumulation [41]. Furthermore, the charge of Ag ions changing to negative may be influenced by the biomolecules from the plant extract attached to them as negative ionizable groups [42]. Negative zeta potential for AgNPs prepared by F. asafoetida might be related to carboxyl and hydroxyl groups of ferulic acid that capped the AgNPs surface [40]. Different plant extracts with different extraction methods showed different abilities for the preparation of AgNPs since different particle sizes and potential were observed (Table 1). 


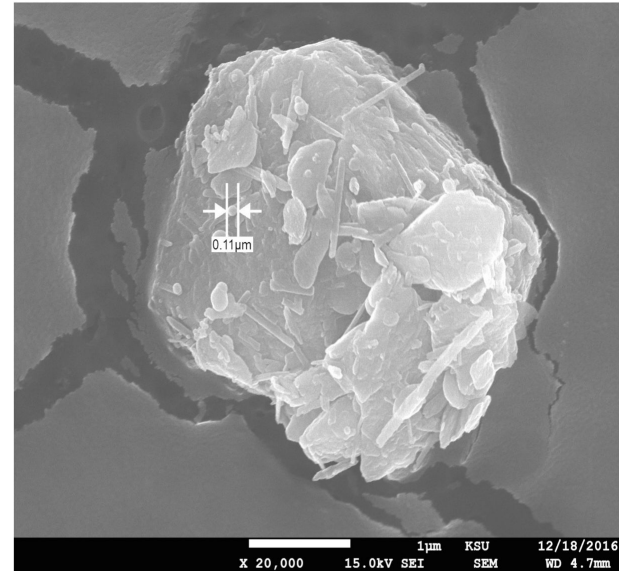

(a)

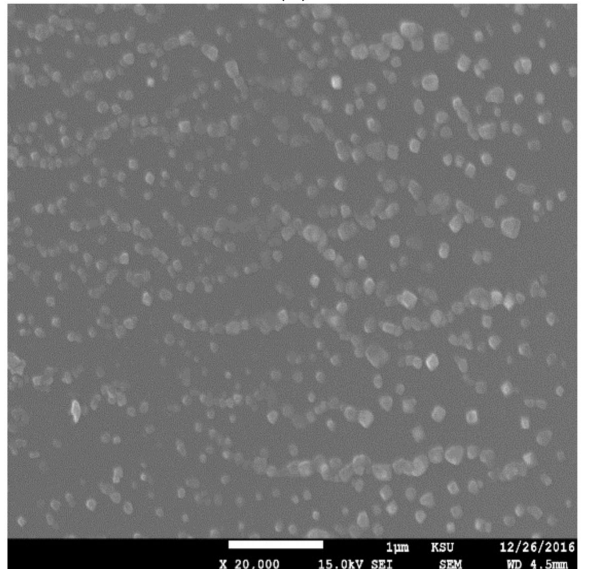

(c)

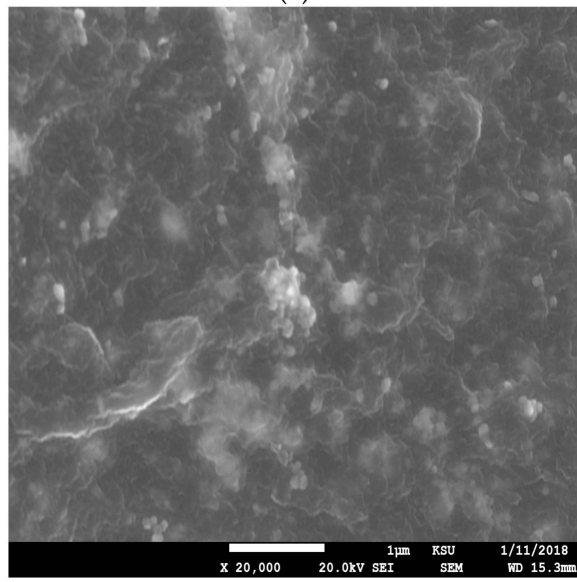

(e)

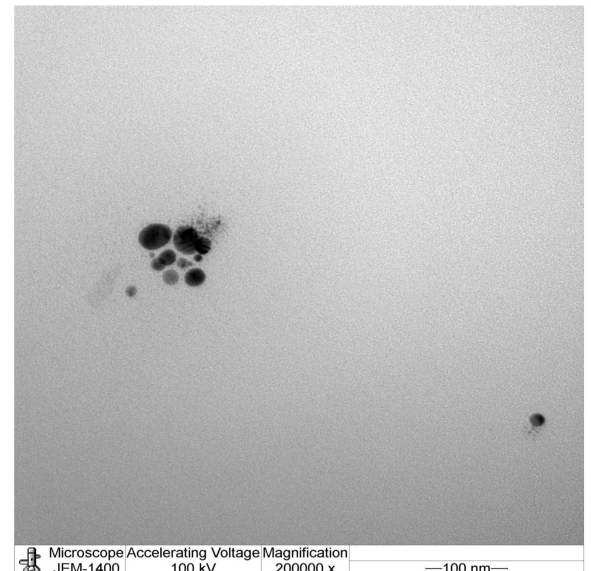

(b)

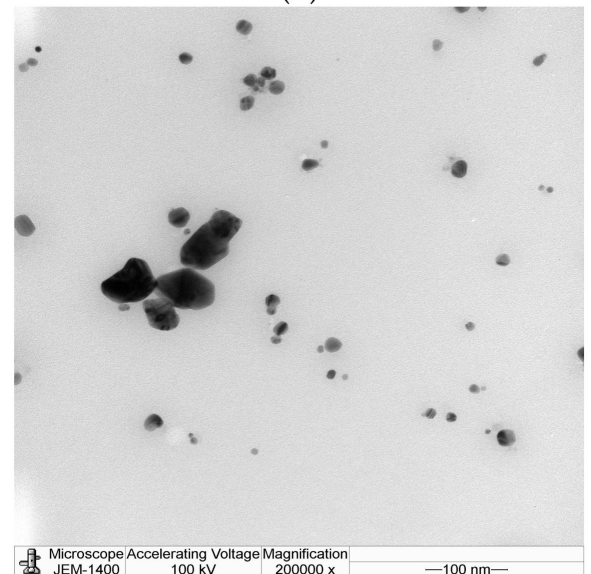

(d)

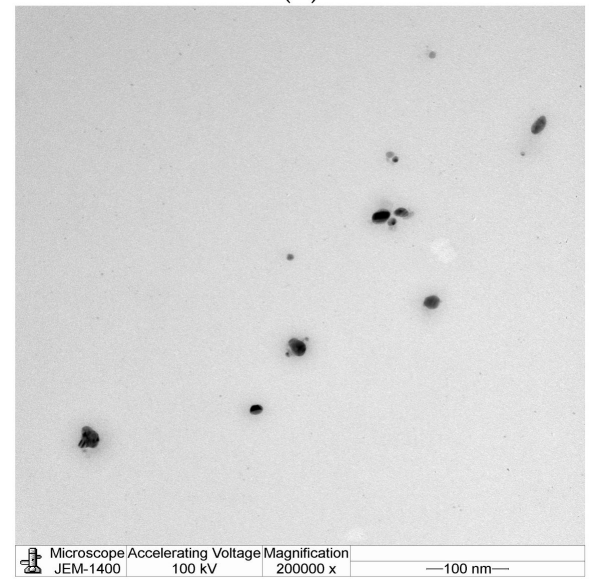

(f)

Figure 1. Scanning electron microscope $(\mathrm{SEM})$ images $(\mathbf{a}-\mathbf{c})$ and the corresponding transmission electron microscopy (TEM) images (d-f) of silver nanoparticles obtained using alcoholic extracts of Phoenix dactylifer, Acacia nilotica, and Ferula asafetida. Magnification is 20,000 $\times$ and the scale bar represents $100 \mathrm{~nm}$ for TEM images and $1 \mu \mathrm{m}$ for SEM images. 
Table 1. Average particle size (nm), Average Zeta potential $(\mathrm{mV})$ of biogenic synthesized silver nanoparticles (AgNPs) and their Zone of inhibition (mm) against Escherichia coli, Staphylococcus aureus, and Pseudomonas aeruginosa.

\begin{tabular}{|c|c|c|c|c|c|}
\hline \multirow{2}{*}{ Treatment } & \multirow{2}{*}{$\begin{array}{l}\text { Average Particle } \\
\text { Size }(\mathrm{nm})\end{array}$} & \multirow{2}{*}{$\begin{array}{l}\text { Average Zeta } \\
\text { Potential }(\mathrm{mV})\end{array}$} & \multirow{2}{*}{$\begin{array}{c}\begin{array}{c}\text { Inhibition Zone + } \\
\text { Gram (mm) }\end{array} \\
\text { S. aureus }\end{array}$} & \multicolumn{2}{|c|}{ Inhibition Zone - Gram (mm) } \\
\hline & & & & E. coli & P. aeruginosa \\
\hline $\mathrm{AKN}$ & $121.3 \pm 1.1$ & $-14 \pm 1$ & $14.5 \pm 1.5$ & $15.8 \pm 0.8$ & $14.0 \pm 0.6$ \\
\hline $\mathrm{AWN}$ & $67.8 \pm 0.3$ & $-5.4 \pm 0.3$ & $17.8 \pm 1.3$ & $11.8 \pm 1.0$ & $15.1 \pm 0.8$ \\
\hline GKN & $147 \pm 2.5$ & $-13.2 \pm 0.2$ & $13.4 \pm 2$ & $19.6 \pm 2.0$ & 14.10 .5 \\
\hline GWN & $100.4 \pm 0.9$ & $-0.2 \pm 0.3$ & $11.2 \pm 0.1$ & $12.0 \pm 1.4$ & $15.8 \pm 0.1$ \\
\hline $\mathrm{HKN}$ & $155.7 \pm 1.5$ & $-12 \pm 0.7$ & $11.8 \pm 1.6$ & $10.3 \pm 1.1$ & $14.6 \pm 2.6$ \\
\hline HWN & $105.7 \pm 0.6$ & $-0.2 \pm 0.6$ & $10.0 \pm 0.5$ & $10.7 \pm 2.0$ & 0 \\
\hline AK & - & - & $32.2 \pm 0.1$ & $18 \pm 0.3$ & $18.8 \pm 0.5$ \\
\hline AW & - & - & $23.4 \pm 2.4$ & 0 & $14.1 \pm 0.4$ \\
\hline GK & - & - & $21.2 \pm 2$ & $19.6 \pm 2$ & $14.1 \pm 0.5$ \\
\hline GW & - & - & $10.6 \pm 1.2$ & 0 & 0 \\
\hline HK & - & - & 0 & 0 & 0 \\
\hline HW & - & - & 0 & 0 & 0 \\
\hline Ag ions & - & - & 1.3 & 1.5 & 1 \\
\hline Amoxicillin (AMO) & - & - & $22.9 \pm 0.5$ & $17.9 \pm 0.7$ & 0 \\
\hline Cefuroxime (CXM) & - & - & $29.4 \pm 1.0$ & $26.9 \pm 0.5$ & 0 \\
\hline Ciprofloxacin (CIP) & - & - & $27 \pm 1.9$ & $35 \pm 2.0$ & $37 \pm 0.6$ \\
\hline
\end{tabular}

Data expressed as mean $\pm \mathrm{SD}$. AKN $=$ AgNPs prepared by alcoholic extract of Phoenix dactylifer, $\mathrm{AWN}=\mathrm{AgNPs}$ prepared by aqueous extract of Phoenix dactylifer, GKN = AgNPs prepared by alcoholic extract of Acacia nilotica, $\mathrm{GWN}=$ AgNPs prepared by aqueous ethanolic extract of Acacia nilotica, $\mathrm{HKN}=$ AgNPs prepared by alcoholic extract of Ferula asafoetida, HWN = AgNPs prepared by aqueous extract of Ferula asafetida. AK, GK and HK = alcoholic extract of Phoenix dactylifer, Acacia nilotica and Ferula asafetida respectively and AW, GW and HW = aqueous extract of Phoenix dactylifer, Acacia nilotica and Ferula asafetida respectively.

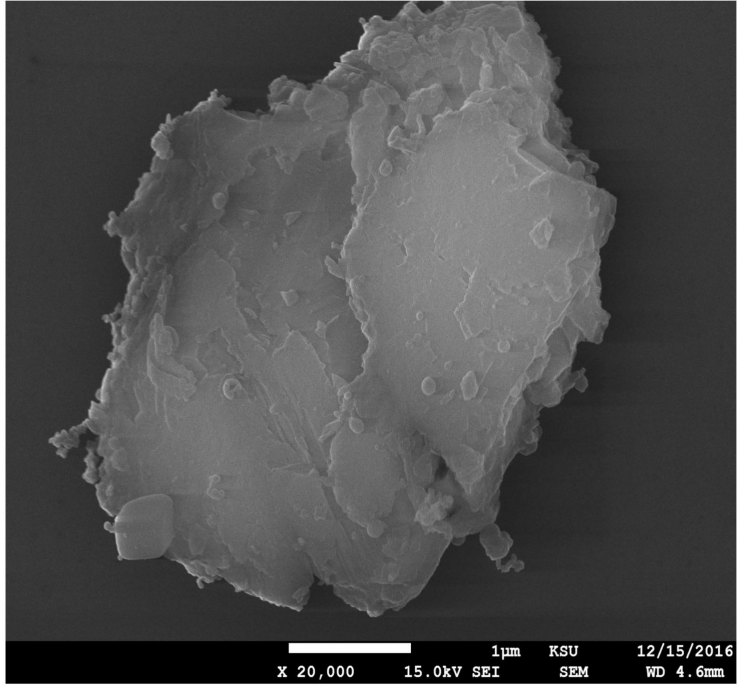

(a)

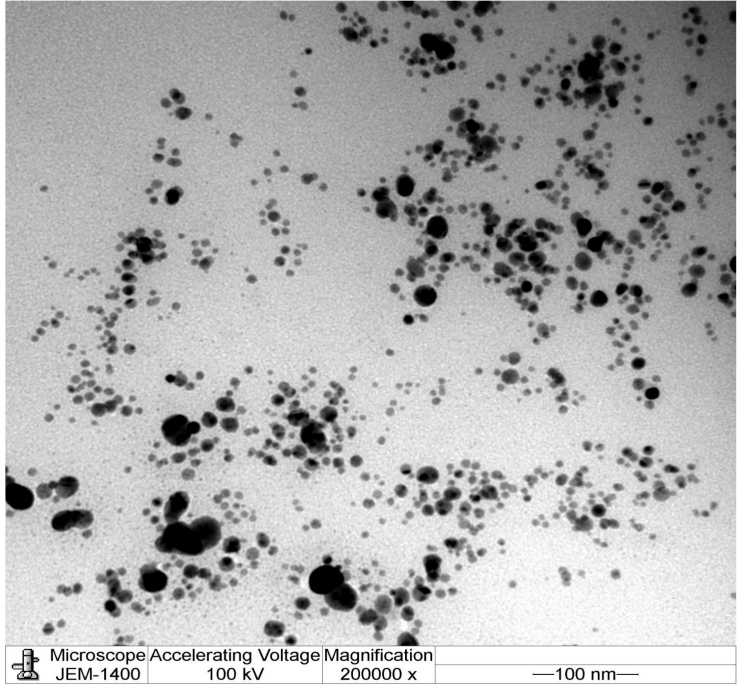

(b)

Figure 2. Cont. 


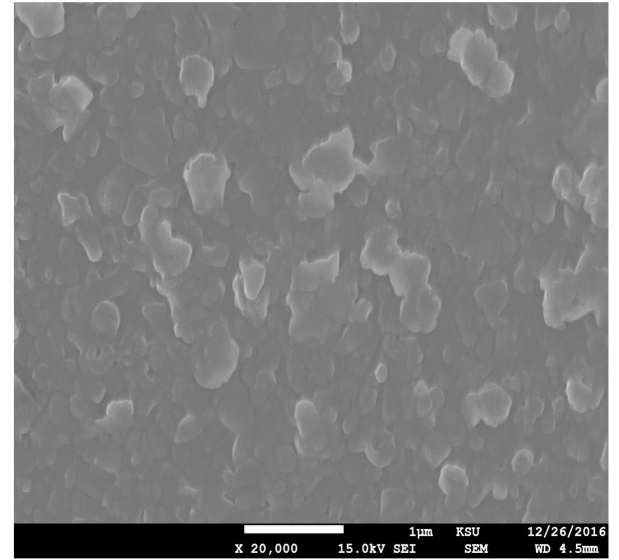

(c)

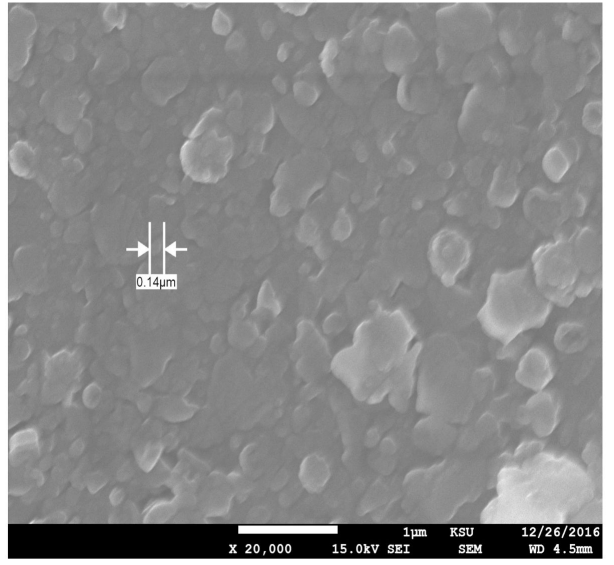

(e)

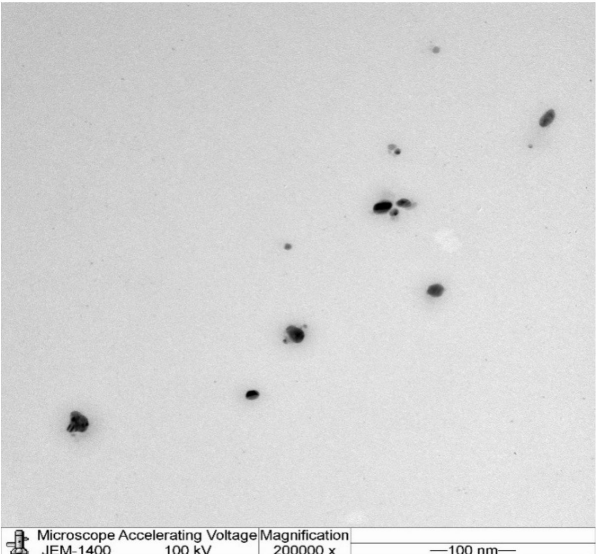

(d)

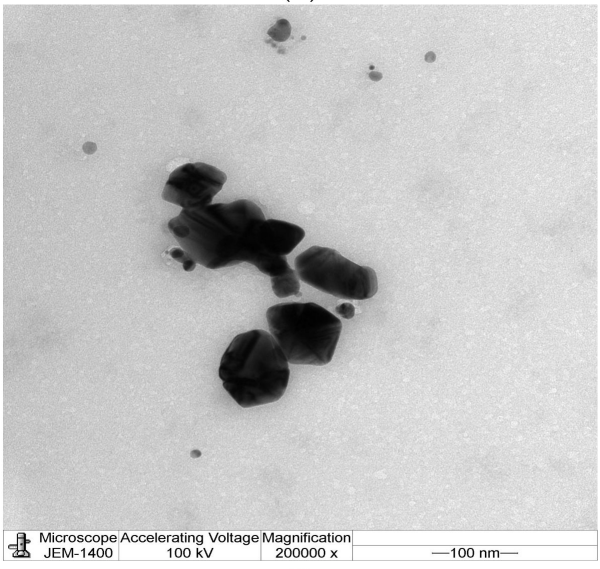

$(\mathbf{f})$

Figure 2. SEM images $(\mathbf{a}-\mathbf{c})$ and the corresponding TEM images $(\mathbf{d}-\mathbf{f})$ of silver nanoparticles obtained using aqueous extracts of Phoenix dactylifer, Acacia nilotica, and Ferula asafetida. Magnification is 20,000× and scale bar represents $100 \mathrm{~nm}$ for TEM images and $1 \mu \mathrm{m}$ for SEM images.

\subsection{Fourier-Transform Infrared Spectroscopy}

The FT-IR measurements were taken for the determination of biomolecules that bound to the silver ion particles and act as reducing, capping, and stabilizing agents. The present results showed wide ranges of absorption peaks for the different plant extracts with different extraction methods used. AgNPs prepared by Phoenix dactylifera showed a range of $423-3310 \mathrm{~cm}^{-1}$, and those prepared by Acacia nilotica showed a range of $416-3311 \mathrm{~cm}^{-1}$ while those prepared by Ferula asafoetida showed a range of $430-3316 \mathrm{~cm}^{-1}$, indicating that different molecules were expected in each extract (Supplementary Materials Figure S1). Peaks at $3268-3432 \mathrm{~cm}^{-1}$ might indicate the stretching vibrations of $\mathrm{H}$-bonded $\mathrm{OH}$ groups that may be found in alcohol, phenol groups, or glycosides [43]. Bands at 2158-2163 $\mathrm{cm}^{-1}$ might be attributed to CO hydrogen-bonded with hydroxyl groups [44]. The obtained bands from different extracts at 1632,1633, and $1634 \mathrm{~cm}^{-1}$ might correspond to amide bands in proteins. Absorbance between 1600 and $1700 \mathrm{~cm}^{-1}$ may show the amide I vibration for proteins that could be related to $\mathrm{C}=\mathrm{O}$ stretching vibration [45]. Peaks found in the current study were near $1633 \mathrm{~cm}^{-1}$, which was also reported for native protein indicating that the protein interacting with AgNPs did not change after binding [46]. Bands of about $1634 \mathrm{~cm}^{-1}$ were recorded when Jatropha gossypifolia was used as a bioreductant agent for AgNPs synthesis [47]. Bands at 380-580 could be related to aromatic nitrile [48]. Clear bands in the current study may suggest the presence of some organic compounds such as phenolic, glycosides, or protein in plant extracts that could be acting as stabilizing 
and capping agents for AgNPs. Phenolic, carboxyl and carbonyl functional groups were also detected by Farhadi et al. [41] for NPs prepared by Phoenix dactylifera.

\subsection{Antibacterial Activity of Biogenic AgNPs}

Biogenic AgNPs showed potent bactericidal action against tested bacterial species except AgNPs prepared by aqueous extract of $F$. asafoetida against $P$. aeruginosa. Plant aqueous extract and $\mathrm{AgNO}_{3}$ solution showed low antibacterial activity compared with plant alcoholic extract. The liposolubility of plant compounds could be the main reason for such activity since the bacterial cell membrane allows only for lipid soluble substances to penetrate the bacterial cell [49]. From the current study, it was clear that the ability of different plant extracts to make AgNPs from silver nitrate differs according to the plant extract and different extraction methods used; therefore, different antibacterial activity was noticed. AgNPs prepared by aqueous and alcoholic extracts mostly showed antibacterial ability against tested microbes. AgNPs prepared by Phoenix dactylifer and Acacia nilotica ethanolic extracts showed more than $50 \%$ of the antibacterial activity of Amoxicillin against S. aureus. AgNPs prepared by Phoenix dactylifer aqueous extract showed more than $85 \%$ of the Amoxicillin activity. More than $40 \%$ of Cefuroxime activity was noticed for AgNPs prepared by Phoenix dactylifer aqueous extract against $S$. aureus. Regarding E. coli, about $60 \%, 50 \%$, and $30 \%$ of the activity of Amoxicillin, Cefuroxime, and Ciprofloxacin, respectively, was observed for AgNPs, but such nanoparticles were more active than Amoxicillin and Cefuroxime against P. aeruginosa. About $40 \%$ of the Ciprofloxacin activity was noticed for AgNPs except for those prepared by F. asafetida, which showed no ability against P. aeruginosa. Antibacterial activity of AgNPs prepared by plant extract were well documented [50,51]. On the other hand, ethanolic extract of Phoenix dactylifer and Acacia nilotica showed high antibacterial activity against all tested microbes. From the current results, it is clear that the antibacterial activity of the AgNPs that were prepared from aqueous plant extracts cannot be related to the plant extract or silver nitrate alone since the AgNPs showed a greater ability to suppress microbial growth in comparison to them. Furthermore, no special trend of inhibiting activity against gram-negative species was observed, suggesting that the AgNPs activity was not related to the structure of the bacterial cell wall.

\subsubsection{Tolerance Determination}

An additional examination for biogenic AgNPs antibacterial potential was done at different concentration levels to determine the MIC and MBC for the tested bacterial strain. The values of the MIC and the MBC for AgNPs against all tested bacteria ranged between 12.5 to $75 \mu \mathrm{g} / \mathrm{mL}$. Furthermore, the MBC/MIC ratio may reflect the susceptibility, tolerance, or resistance of the bacteria to the tested agent [52]. For all tested strains, the tolerance levels for AgNPs were two or less than two, which indicates that the AgNPs prepared by different biological materials in the current study are considered bactericidal agents [38].

\subsubsection{Synergistic Antimicrobial Potential of AgNPs}

The synergistic potential of the AgNPs together with the standard antibiotics, Amoxicillin, Cefuroxime, and Ciprofloxacin, were tested against E. coli, S. aureus, and P. aeruginosa, with the results presented in (Table 2). Different types of antibiotics have a different mode of action against bacteria: Cefuroxime and Amoxicillin act by inhibiting bacterial cell wall synthesis, and Ciprofloxacin inhibits the enzyme bacterial DNA gyrase and prevents bacterial DNA replication during bacterial growth and reproduction [53]. Both antibiotics and AgNPs were mixed at their low concentration and their activities were evaluated. The effect was observed against tested bacteria, but P. aeruginosa showed resistance when treated with AgNPs mixed with Amoxicillin and some AgNPs mixed with Cefuroxime. Mixing AgNPs with Ciprofloxacin showed strong positive antibacterial activity against all tested microbes. [53-56] suggested that a better interaction of the mixture with the pathogen due to the bonding reaction may lead to a positive synergistic effect of AgNPs-antibiotics mixture when some MDR bacteria were studied. Active uptake of the AgNPs-ciprofloxacin mixture by bacteria could 
be the reason for the cells damage since the ciprofloxacin inhibits the enzyme bacterial DNA gyrase and prevents DNA replication [53]. Generally, synergistic abilities of AgNPs with the antibiotics may reduce the use of antibiotics and therefore, reduce the development of antibiotic resistant microbes. In the current study, no special trends or observations were recorded when the synergistic impact of antibiotics in combination with AgNPs were investigated against tested bacteria [53]. Furthermore, different biogenic AgNPs from different backgrounds showed different synergistic effects against different tested strains. On the other hand, the SEM micrograph for Pseudomonas sp. showed a relative change in the bacterial membrane morphology when treated bacteria was tested but also the cell was short compared with a normal cell (Figure 3). The mechanism for AgNPs against bacteria is not absolutely understood, but [28] Das et al. assumed that morphological changes in the bacterial membrane may affect the permeability and therefore cell death may appear.

Table 2. Zone of inhibition, $\mathrm{mm}$ as an effect of different antibiotics (Amoxicillin (AMOX), Cefuroxime (CEF) and Ciprofloxacin (CIP)) in combination with AgNPs at MIC (50 mg/L) against Escherichia coli, Staphylococcus aureus and Pseudomonas aeruginosa.

\begin{tabular}{ccccc}
\hline Treatment & Microbes & AMOX & CEF & CIP \\
\hline \multirow{4}{*}{ ATB +1} & E. coli & 0 & $25 \pm 1$ & $27.7 \pm 0.5$ \\
& S. aureus & $16 \pm 0.5$ & $33.3 \pm 1.5$ & $24.7 \pm 0.5$ \\
& P. aeruginosa & 0 & $7.7 \pm 1.5$ & $36.3 \pm 1.7$ \\
\hline \multirow{4}{*}{ ATB +2} & E. coli & $8.3 \pm 0.5$ & $21.8 \pm 0.5$ & $28 \pm 1$ \\
& S. aureus & $18.3 \pm 0.5$ & $31.3 \pm 2.5$ & $24.7 \pm 0.5$ \\
& P. aeruginosa & 0 & 0 & $32.7 \pm 1.2$ \\
\hline \multirow{4}{*}{ ATB +3} & E. coli & 0 & $24.3 \pm 0.5$ & $26.7 \pm 0.5$ \\
& S. aureus & $15.3 \pm 2.1$ & $26 \pm 1$ & $23.7 \pm 0.5$ \\
& P. aeruginosa & 0 & 0 & $31.7 \pm 1.5$ \\
\hline ATB +4 & E. coli & $7.3 \pm 0.5$ & $23 \pm 0$ & $24 \pm 0$ \\
& S. aureus & $16.7 \pm 0.5$ & $28.3 \pm 0.5$ & $22.3 \pm 0.5$ \\
& P. aeruginosa & 0 & 0 & $30.3 \pm 0.5$ \\
\hline \multirow{4}{*}{ ATB +5} & E. coli & 0 & $22 \pm 1$ & $34 \pm 0$ \\
& S. aureus & $15.7 \pm 0.5$ & $28.7 \pm 1.5$ & $28 \pm 1$ \\
& P. aeruginosa & 0 & $8 \pm 1.7$ & $30.7 \pm 2$ \\
\hline \multirow{2}{*}{ ATB +6} & E. coli & $9.3 \pm 0.5$ & $29.3 \pm 0.5$ & $26.3 \pm 0.5$ \\
& S. aureus & $18 \pm 1$ & $30 \pm 0$ & $26.3 \pm 1.5$ \\
& P. aeruginosa & 0 & 0 & $25.7 \pm 0.5$ \\
\hline
\end{tabular}

Data expressed as mean \pm SD. 1 = AgNPs prepared by aqueous extract of Ferula asafetida, 2 = prepared by ethanolic extract of Ferula asafetida, $3=$ prepared by aqueous extract of Acacia nilotica, $4=$ prepared by aqueous ethanolic extract of Acacia nilotica, 5 = prepared by aqueous extract of Phoenix dactylifer, $6=$ prepared by aqueous ethanolic extract of Phoenix dactylifer.

\subsection{Cell Viability Study}

The cytotoxic potency of AgNPs mediated by a plant extract was tested against human colon cancer LoVo cell lines by the MTT test. There was no activity for AgNPs prepared by aqueous plants extract against tested cells, but AgNPs prepared by ethanolic plant extract showed a clear cytotoxic effect. $46.15 \pm 2.0,58.02 \pm 2.1$, and $69.73 \pm 2.02 \mu \mathrm{g} / \mathrm{mL}$ are the IC50 values for AgNPs mediated by Ferula asafetida, Acacia nilotica, and Phoenix dactylifer, respectively. The silver nanoparticles showed good anticancer activity against LoVo cells line with IC50 values lower than that as reported by [57], and they reported against HCT-116 Colon Cancer Cells when Commelina nudiflora L. Aqueous Extract was used for the biogenic synthesis of AgNPs [58]. The antitumor ability of asafoetida on breast cancer is well-documented [59]. Current investigations show significant antiproliferative action of biosynthesized AgNPs by alcoholic plant extract against LoVo cell lines that may lead to growth cell suppression. Such an ability could be related to the synergetic effect of the biosynthesized nanoparticles and the bioactive molecules attached to their surface [57]. Furthermore, it could be assumed that active 
secondary metabolites that have an antitumor effect were more effective when dissolved in alcohol than in water. In anticancer treatment research, apoptosis as a biological tool that destroys the abnormal cells is considered a smart screening procedure [60]. Generally, a series of modifications appear as a sign of apoptosis or morphologically programmed cell deaths such as chromatin and cytoplasm condensation [61]. In the current study, a phase contrast microscope was used for morphological observations; normally developed cells in the control group that adhered to the bottom of the plate with round cell nuclei were noticed. Following treatment with IC50 concentrations of AgNPs mediated by ethanolic plant extract for $72 \mathrm{~h}$, apoptosis-like symptoms appeared in the cell such as cytoplasmic condensation and detachment from the neighboring cell, swelling of the cell, and a rounded shape. Generally, an increase in the number of apoptosis-like bodies in the tested LoVo cells was observed (Figure 4). Moreover, Buttacavoli et al. [62] detected a similar trend in their observations when they studied the bio-generated silver nanoparticles against human breast cancer cell lines. Generally, cellular morphological changes in the cell might be due to the disturbance in cell composition due to the cell surface and AgNPs interaction [63].

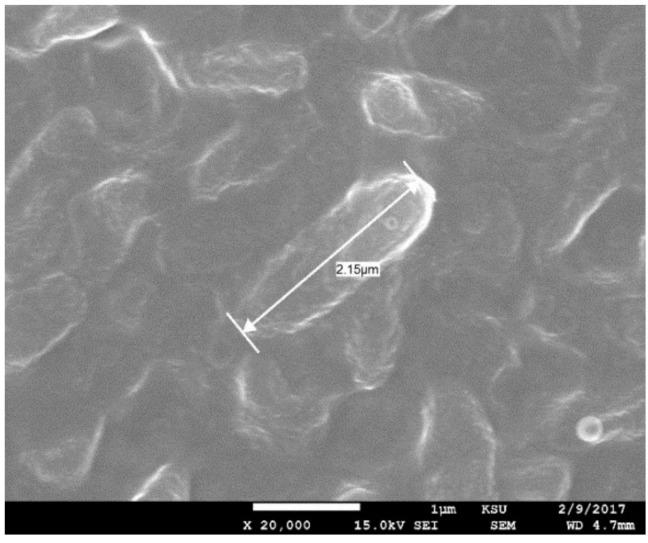

(a)

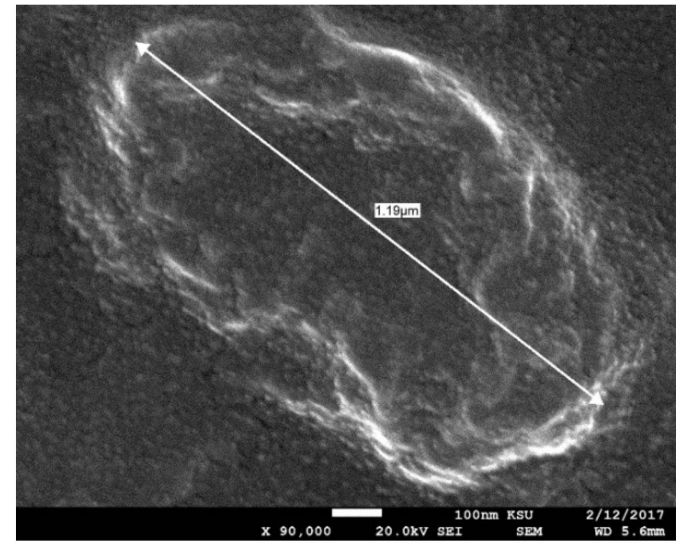

(b)

Figure 3. SEM micrograph of Pseudomonas aeruginosa loaded with AgNPs (a) normal cell (b) treated cell with AgNPs with abnormal cell wall which is also short compared to the untreated cells.

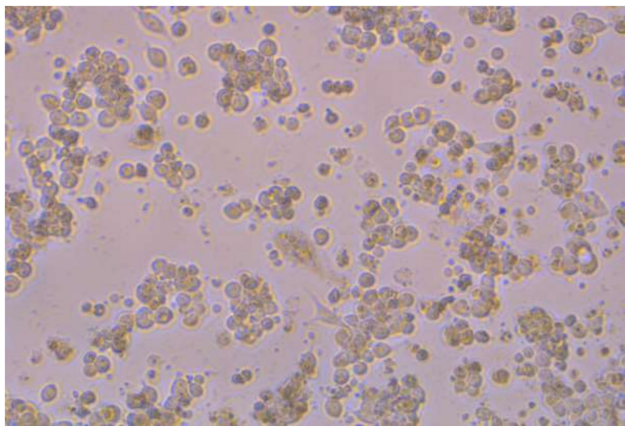

(a)

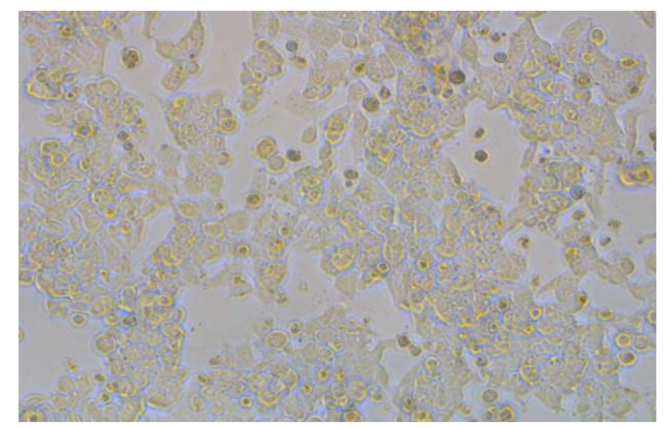

(b)

Figure 4. Morphological changes in LoVo cells treated with $46.15 \mu \mathrm{g} / \mathrm{mL}$ AgNPs mediated by Ferula asafetida extracts for $72 \mathrm{~h}(\mathbf{b})$; (a) is the control. Images were captured by a phase contrast microscope (Leica, Germany), (Magnification: 200×).

Based on similar studies, our current investigation has generated interesting findings that can be expressed in useful applications. Such advantages include the success of our plant extracts in the rapid formation of small AgNPs (67.8-155.7 nm) from $\mathrm{AgNO}_{3}$, the prepared NPs exhibited antimicrobial activity against E. coli, S. aureus, and P. aeruginosa close to that of commercial antibiotics and in some cases even greater. Also, the prepared NPs via our plant extract possessed cytotoxicity against LoVo 
cell lines; therefore, the plant extracts used in synthesizing AgNPs could be considered as an added value in the development of nano-medicine and pharmaceutical production for the treatment of cancer cells and pathogenic microorganisms.

\section{Conclusions}

Antibiotics and anticancer chemotherapeutic drugs are very costly and toxic, besides being a drug resistance problem. Consequently, looking for alternative medicines is essential. Silver nanoparticles produced with an eco-friendly approach is efficient, boasts limited side effects, and less cost. In the current investigation, the aqueous and alcoholic extract of Ferula asafetida, Acacia nilotica, and Phoenix dactylifer showed the ability to produce AgNPs from $\mathrm{AgNO}_{3}$; such particles had an ability to suppress the growth of some pathogenic microorganisms and colon cancer cells. Therefore, this AgNP should be seriously considered as an antibiotic and anticancer drug. Our investigations in the future will focus mainly on answering specific questions and the knowledge gained will enhance our understanding of the machinery of the nanoparticles and will integrate the picture for biological and biotechnological applications.

Supplementary Materials: The following are available online at http:/ /www.mdpi.com/2079-4991/8/6/382/s1, Figure S1: FTIR spectra of synthesized silver nanoparticles by the alcoholic and aqueous extract of Phoenix dactylifer, Acacia nilotica and Ferula asafetida.

Author Contributions: A.E.M. and K.A. designed, conceived of the experiments, performed parts of the experiment, and contributed to the writing of the paper. A.A.-Q., A.a.-M., B.A.-S. performed the efficacy evaluation experiments as undergraduate students.

Funding: This research received no external funding.

Acknowledgments: Authors gratefully acknowledge the Faculty of Science, Princess Nourah Bent Abdul-Rahman University for providing facilities to conduct this work.

Conflicts of Interest: The authors declare no conflict of interest.

\section{References}

1. Thuesombat, P.; Hannongbua, S.; Akasit, S.; Chadchawan, S. Ecotoxicology and environmental safety effect of silver nanoparticles on rice (Oryza sativa L. cv. KDML 105) seed germination and seedling growth. Ecotoxicol. Environ. Saf. 2014, 104, e302-e309. [CrossRef] [PubMed]

2. El-Chaghaby, G.A.; Ahmad, A.F. Biosynthesis of silver nanoparticles using pistacia lentiscus leaves extract and investigation of their antimicrobial effect. Orient. J. Chem. 2011, 27, e929-e936.

3. Veerasamy, R.; Xin, T.Z.; Gunasagaran, S.; Xiang, T.F.W.; Yang, E.F.C.; Jeyakumar, N.; Dhanaraj, S.A. Biosynthesis of silver nanoparticles using mangosteen leaf extract and evaluation of their antimicrobial activities. J. Saudi Chem. Soc. 2011, 15, e113-e120. [CrossRef]

4. Abalkhila, T.A.; Alharbia, S.A.; Salmena, S.H.; Wainwright, M. Bactericidal activity of biosynthesized silver nanoparticles against human pathogenic bacteria. Biotechnol. Biotechnol. Equip. 2017, 31, 411-417. [CrossRef]

5. Nazem, A.; Mansoori, G.A. Nanotechnology solutions for Alzheimer's disease: Advances in research tools, diagnostic methods and therapeutic agents. J. Alzheimers Dis. 2008, 13, 199-223. [CrossRef] [PubMed]

6. Jacob, S.J.P.; Finub, J.S.; Narayanan, A. Synthesis of silver nanoparticles using Piper longum leaf extracts and its cytotoxic activity against Hep-2 cell line. Colloids Surf. Biointerfaces 2012, 91, 212-214. [CrossRef] [PubMed]

7. Bindhu, M.R.; Umadevi, M. Antibacterial and catalytic activities of green synthesized silver nanoparticles. Spectrochim. Acta A Mol. Biomol. Spectrosc. 2015, 135, e373-e378. [CrossRef] [PubMed]

8. Mahdi, S.; Taghdiri, M.; Makari, V.; Rahimi-Nasrabadi, M. Procedure optimization for green synthesis of silver nanoparticles by aqueous extract of Eucalyptus oleosa. Spectrochim. Acta A Mol. Biomol. Spectrosc. 2015, 136, e1249-e1254.

9. Padalia, H.; Moteriya, P.; Chanda, S. Green synthesis of silver nanoparticles from marigold flower and its synergistic antimicrobial potential. Arab. J. Chem. 2014. [CrossRef] 
10. Sre, P.R.R.; Reka, M.; Poovazhagi, R.; Kumar, M.A.; Murugesan, K. Antibacterial and cytotoxic effect of biologically synthesized silver nanoparticles using aqueous root extract of Erythrina indica. Spectrochim. Acta A Mol. Biomol. Spectrosc. 2015, 135, e1137-e1144.

11. Mittal, J.; Batra, A.; Singh, A.; Sharma, M.M. Phytofabrication of nanoparticles through plant as nanofactories. Adv. Nat. Sci. Nanosci. Nanotechnol. 2014, 5, 04300. [CrossRef]

12. Mohammed, A.E. Arta (Calligonum Comosum, L'Her.) Shoot Extracts: Bio-Mediator in Silver Nanoparticles Formation and Antimycotic Potential. Nano Biomed. Eng. 2016, 8, 128-135. [CrossRef]

13. Mohammed, A.E.; Albrahim, J.S. Synthesis, Characterization and Evaluation of Antimicrobial Potency of Silver Nanoparticles Using ZiziphusSpina-christi L. Leaf Extract. J. Pure Appl. Microbiol. 2014, 8, 3903-3908.

14. Mohammed, A.E. Green Synthesis and Antimicrobial Activity of Eucalyptus camaldulensis Mediated Silver Nanoparticles. Asian Pac. J. Trop. Biomed. 2015, 5, 930-934. [CrossRef]

15. Sadeghi, B.; Gholamhoseinpoor, F. A study on the stability and green synthesis of silver nanoparticles using Ziziphora tenuior $(\mathrm{Zt})$ extract at room temperature. Spectrochim. Acta A Mol. Biomol. Spectrosc. 2015, 134, e310-e315. [CrossRef] [PubMed]

16. Ahmed, S.; Ahmad, M.; Swami, B.L.; Ikram, S. Green synthesis of silver nanoparticles using Azadirachta indica aqueous leaf extract. J. Radiat. Res. Appl. Sci. 2016, 9, 1-7. [CrossRef]

17. Saklani, V.; Suman, J.V.K. Microbial Synthesis of Silver Nanoparticles: A Review. J. Biotechnol. Biomater. 2012, 13, 007. [CrossRef]

18. Mahmoud, W. M.; Abdelmoneim, T.S.; Elazzazy, A.M. The Impact of Silver Nanoparticles Produced by Bacillus pumilus As Antimicrobial and Nematicide. Front. Microbiol. 2016, 7, 1746. [CrossRef] [PubMed]

19. Vigneshwaran, N.; Ashtaputre, N.M.; Varadarajan, P.V.; Nachane, R.P.; Paralikar, K.M.; Balasubramanya, R.H. Biological synthesis of silver nanoparticles using the fungus Aspergillus flavus. Mater. Lett. 2007, 66, 1413-1418. [CrossRef]

20. Sintubin, L.; De Windt, W.; Dick, J.; Mast, J.; Ha, D.V.; Verstraete, W.; Boon, N. Lactic acid bacteria as reducing and capping agent for the fast and efficient production of silver nanoparticles. Appl. Microbiol. Biotechnol. 2009, 84, 741-749. [CrossRef] [PubMed]

21. Kalishwaralal, K.; Deepak, V.; Ramkumarpandian, S.; Nellaiah, H.; Sangiliyandi, G. Extracellular biosynthesis of silver nanoparticles by the culture supernatant of Bacillus licheniformis. Mater. Lett. 2008, 62, 4411-4413. [CrossRef]

22. Ganesh, B.M.M.; Gunasekaran, P. Production and structural characterization of crystalline silver nanoparticles from Bacillus cereus isolate. Colloids Surf. B 2009, 74, 191-195. [CrossRef] [PubMed]

23. Ahmed, S.; Ahmad, M.; Swami, B.L.; Ikram, S. Plants extract mediated synthesis of silver nanoparticles for antimicrobial applications: A green expertise. J. Adv. Res. 2016, 7, 17-28. [CrossRef] [PubMed]

24. Jha, A.; Prasad, K.; Prasad, K.; Kulkarni, A.R. "Plant system: Nature's nanofactory”. Colloids Surf. B Biointerfaces 2009, 73, 219-223. [CrossRef] [PubMed]

25. Alshaye, N.A.; Elobeid, M.M.; Alkhalifah, D.H.M.; Mohammed, A.E. Characterization of Biogenic Silver Nanoparticles by Salvadora persica leaves extract and Its Application Against Some MDR Pathogens E. coli and S. Aureus. Res. J. Microbiol. 2017, 12, 74-81. [CrossRef]

26. Rai, M.K.; Deshmukh, S.D.; Ingle, A.P.; Gade, A.K. Silver nanoparticles: The powerful nanoweapon against multidrug-resistant bacteria. J. Appl. Microbiol. 2012, 112, 841-852. [CrossRef] [PubMed]

27. Birla, S.; Tiwari, V.; Gade, A.; Ingle, A.; Yadav, A.; Rai, M. Fabrication of silver nanoparticles by Phoma glomerala and its combined effect against Escherichia coli, Pseudomonas aeruginosa and Staphylococcus aureus. Lett. Appl. Microbiol. 2009, 48, 173-179. [CrossRef] [PubMed]

28. Das, P.; Xenopoulos, M.A.; Williams, C.J.; Hoque, M.E.; Metcalfe, C.D. Effects of silver nanoparticles on bacterial activity in natural waters. Environ. Toxicol. Chem. 2012, 31, 122-130. [CrossRef] [PubMed]

29. Khatami, M.; Pourseyedi, S. Phoenix dactylifera (date palm) pit aqueous extract mediated novel route for synthesis high stable silver nanoparticles with high antifungal and antibacterial activity. IET Nanobiotechnol. 2015, 9, 184-190. [CrossRef] [PubMed]

30. Aitenneite, H.; Abboud, Y.; Tanane, O.; Solhy, A.; Sebti, S.; El Bouari, A. Rapid and green microwave-assisted synthesis of silver nanoparticles using aqueous Phoenix Dactylifera L. (date palm) leaf extract and their catalytic activity for 4-Nitrophenol reduction. J. Mater. Environ. Sci. 2016, 7, 2335-2339. 
31. Tahir, K.; Nazir, S.; Ahmad, A.; Li, B.; Shah, S.A.A.; Khan, A.U.; Khan, G.M.; Khan, Q.U.; Khan, Z.U.H.; Khan, F.U. Biodirected synthesis of palladium nanoparticles using Phoenix dactylifera leaves extract and their size dependent biomedical and catalytic applications. RSC Adv. 2016, 6, 85903-85916. [CrossRef]

32. Ragab, A.R.; Elkablawy, M.A.; Sheik, B.Y.; Baraka, H.N. Antioxidant and Tissue-Protective Studies on Ajwa Extract: Dates from Al Madinah Al-Monwarah, Saudia Arabia. J. Environ. Anal. Toxicol. 2013, 3, 163. [CrossRef]

33. Saleh, E.A.; Tawfik, M.S.; Abu-Tarboush, H.M. Phenolic contents and antioxidant activity of various date palm (Phoenix dactylifera L.) fruits from Saudi Arabia. Food Nutr. Sci. 2011, 2, 1134-1141. [CrossRef]

34. Abdel-Farid, I.B.; Sheded, M.G.; Mohamed, E.A. Metabolomic profiling and antioxidant activity of some Acacia species. Saudi J. Biol. Sci. 2014, 21, 400-440. [CrossRef] [PubMed]

35. Gavade, S.J.M.; Nikam, G.H.; Sabale, S.R.; Tamhankar, B.V. Green synthesis of fluorescent silver nanoparticles using Acacia nilotica gum extract for kinetic studies of 4-nitrophenol reduction. Mater. Today Proc. 2016, 3, 4109-4114. [CrossRef]

36. Iranshahy, M.; Iranshahi, M. Traditional uses, phytochemistry and pharmacology of asafoetida (Ferula assa-foetida oleo-gum-resin) A review. J. Ethnopharmacol. 2011, 134, 1-10. [CrossRef] [PubMed]

37. May, J.; Shannon, K.; King, A.; French, G. Glycopeptide tolerance in Staphylococcus aureus. J. Antimicrob. Chemother. 1998, 42, 189-97. [CrossRef] [PubMed]

38. Woods, G.L.; Washington, J.A. The clinician and the microbiology laboratory. In Principles and Practice of Infectious Diseases; Mandell, G., Bennett, J., Dolin, R., Eds.; Elsevier: New York, NY, USA, 1995.

39. Lim, S.W.; Loh, H.S.; Ting, K.N.; Bradshaw, T.D.; Allaudin, Z.N. Reduction of MTT to Purple Formazan by Vitamin E Isomers in the Absence of Cells. Trop. Life Sci. Res. 2015, 26, 111-120. [PubMed]

40. Sangeetha, J.; Sandhya, J.; Philip, J. Biosynthesis and Functionalization of Silver Nanoparticles Using Nigella sativa, Dioscorea alata and Ferula asafetida. Sci. Adv. Mater. 2014, 6. [CrossRef]

41. Farhadi, S.; Ajerloo, B.; Mohammadi, A. Green Biosynthesis of Spherical Silver Nanoparticles by Using Date Palm (Phoenix Dactylifera) Fruit Extract and Study of Their Antibacterial and Catalytic Activities. Acta Chim. Slov. 2017, 64, 129-143. [CrossRef] [PubMed]

42. Khatoon, N.; Mazumder, J.A.; Sardar, M. Biotechnological Applications of Green Synthesized Silver Nanoparticles. J. Nanosci. Curr. Res. 2017, 2, 107.

43. Prabu, K.; Natarajan, E. Isolation and FTIR spectroscopy characterization of chitin from local sources. Adv. Appl. Sci. Res. 2012, 3, 1870-1875.

44. Belskaya, O.B.; Danilova, I.G.; Kazakov, M.O.; Mironenko, R.M.; Lavrenov, A.V.; Likholobov, V.A. FTIR Spectroscopy of Adsorbed Probe Molecules for Analyzing the Surface Properties of Supported Pt (Pd) Catalysts; Infrared Spectroscopy-Materials Science, Engineering and Technology; Theophile, T., Ed.; InTech: Rijeka, Croatia, 2012; ISBN 978-953-51-0537-4. Available online: http: / /www.intechopen.com/books/infrared-spectroscopy-materials-science-engineering-and-technology / ftirspectroscopy-of-adsorbed-probe-molecules-for-analyzing-the-surface-properties-of-supported-pt-p (accessed on 10 January 2018).

45. Kong, J.; Yu, S. Acta. fourier transform infrared spectroscopic analysis of protein secondary structures. Biochim. Biophys. Sin. 2007, 39, 549-559. [CrossRef]

46. Macdonald, I.D.G.; Smith, W.E. Orientation of cytochrome C adsorbed on a citrate-reduced silver colloid surface. Langmuir 1996, 12, 706-713. [CrossRef]

47. Nazeem, T.H.; Sugannya, P.K. Synthesis and characterization of silver nanoparticles from two medicinal plants and its anticancer property. Int. J. Res. Eng. Technol. 2014, 2, 49-56.

48. Kumar, V.; Panikar, Y.; Palafox, M.A.; Vats, J.K.; Kostova, I.; Lang, K.; Pastogi, U.K. Ab-initio calculation, FTIR and Ft-Raman spectra of 2-choloro-6-methyle benzonitrile. Indian J. Pure Appl. Phys. 2010, 48, 83-94.

49. Elemike, E.E.; Fayemi, O.E.; Ekennia, A.C.; Onwudiwe, D.C.; Ebenso, E.E. Silver Nanoparticles Mediated by Costus afer Leaf Extract: Synthesis, Antibacterial, Antioxidant and Electrochemical Properties. Molecules 2017, 22, 701. [CrossRef] [PubMed]

50. Alqahtani, M.A.M.; Mohammed, A.E.; Daoud, S.I.; Alkhalifah, D.H. Lichens (Parmotrema clavuliferum) extracts: Bio-mediator in silver nanoparticles formation and its antibacterial potential. J. Bionanosci. 2017, 11, 410-415. [CrossRef] 
51. Afrah, E. Mohammed; Ben Baz, F.F.; Albrahim, J.S. Calligonum comosum and Fusarium sp. extracts as bio-mediator in Silver Nanoparticles formation: Characterization and Antibacterial capability. 3 Biotech 2018, 8, 72. [CrossRef]

52. Das, B.; Dash, S.K.; Mandal, D.; Adhikary, J.; Chattopadhyay, S.; Tripathy, S.; Dey, A.; Manna, S.; Dey, S.K.; Das, D.; et al. Green-synthesized silver nanoparticles kill virulent multidrug-resistant Pseudomonas aeruginosa strains: A mechanistic study, BLDE University. J. Health Sci. 2016, 1, 89-101.

53. Panacek, A.; Smekalova, M.; Kilianova, M.; Prucek, R.; Bogdanova, K.; Vecerova, R.; Kolář, M.; Havrdová, M.; Płaza, G.A.; Chojniak, J.; et al. Strong and nonspecific synergistic antibacterial efficiency of antibiotics combined with silver nanoparticles at very low concentrations showing no cytotoxic effect. Molecules 2016, 21, 26. [CrossRef] [PubMed]

54. McShan, D.; Zhang, Y.; Deng, H.; Ray, P.C.; Yu, H. Synergistic antibacterial effect of silver nanoparticles combined with ineffective antibiotics on drug resistant Salmonella typhimurium DT104. J. Environ. Sci. Health 2015, 33, 369-384. [CrossRef] [PubMed]

55. Barapatre, A.; Aadil, K.R.; Jha, H. Synergistic antibacterial and antibiofilm activity of silver nanoparticles biosynthesized by lignin-degrading fungus. Bioresour. Bioprocess. 2016, 3, 8. [CrossRef]

56. Deng, H.; McShan, D.; Zhang, Y.; Sinha, S.S.; Arslan, Z.; Ray, P.C.; Yu, H. Mechanistic study of the synergistic antibacterial activity of combined silver nanoparticles and common antibiotics. Environ. Sci. Technol. 2016, 50, 8840-8848. [CrossRef] [PubMed]

57. Mohanta, Y.K.; Panda, S.K.; Jayabalan, R.; Sharma, N.; Bastia, A.K.; Mohanta, T.K. Antimicrobial, Antioxidant and Cytotoxic Activity of Silver Nanoparticles Synthesized by Leaf Extract of Erythrina suberosa (Roxb.). Front. Mol. Biosci. 2017, 4, 14. [CrossRef] [PubMed]

58. Kuppusamy, P.; Ichwan, S.J.; Al-Zikri, P.N.; Suriyah, W.H.; Soundharrajan, I.; Govindan, N.; Maniam, G.P.; Yusoff, M.M. In Vitro Anticancer Activity of Au, Ag Nanoparticles Synthesized Using Commelina nudiflora L. Aqueous Extract against HCT-116 Colon Cancer Cells. Biol. Trace Elem. Res. 2016, 173, 297-305. [CrossRef] [PubMed]

59. Bagheri, S.M.; Abdian-As, L.A.; Moghadam, M.T.; Yadegari, M.; Mirjalili, A.; Zare-Mohazabieh, F.; Momeni, H. Antitumor effect of Ferula assa foetida oleo gum resin against breast cancer induced by $4 \mathrm{~T} 1$ cells in BALB/c mice. J. Ayur. Integr. Med. 2017, 8, 152-158. [CrossRef] [PubMed]

60. Aigner, T. Apoptosis, necrosis, or whatever: How to find out what really happens? J. Pathol. 2002, 198, 1-4. [CrossRef] [PubMed]

61. Ciniglia, C.; Pinto, G.; Sansone, C.; Pollio, A. Acridine orange/Ethidium bromide double staining test: A simple invitro assay to detect apoptosis induced by phenolic compounds in plant cells. Allelopathy J. 2010, 26, 301-308.

62. Buttacavoli, M.; Albanese, N.N.; Di Cara, G.; Alduina, R.; Faleri, C.; Gallo, M.; Pizzolanti, G.; Gallo, G.; Feo, S.; Baldiand, F.; et al. Anticancer activity of biogenerated silver nanoparticles: An integrated proteomic investigation. Oncotarget 2017, 9, 9685. [CrossRef] [PubMed]

63. Ramkumar, V.S.; Pugazhendhi, A.; Gopalakrishnan, K.; Sivagurunathan, P.; Saratale, G.D.; Dung, T.N.B.; Kannapiran, E. Biofabrication and characterization of silver nanoparticles using aqueous extract of seaweed Enteromorpha compressa and its biomedical properties. Biotechnol. Rep. 2017, 14, 1-7. [CrossRef] [PubMed]

(C) 2018 by the authors. Licensee MDPI, Basel, Switzerland. This article is an open access article distributed under the terms and conditions of the Creative Commons Attribution (CC BY) license (http://creativecommons.org/licenses/by/4.0/). 